\section{Factors associated with safe sex among public school students in Minas Gerais, Brazil}

\author{
Fatores associados a sexo seguro entre alunos de \\ escolas públicas em Minas Gerais, Brasil
}

\footnotetext{
1 Maternidade Odete Valadares, Fundação Hospitalar de Minas Gerais, Belo Horizonte, Brasil. 2 Unicentro Newton Paiva, Belo Horizonte, Brasil. 3 Centro de Pesquisas Materno-Infantis de Campinas, Campinas, Brasil. ${ }_{4}^{4}$ Faculdade de Ciências Médicas, Universidade Estadual de Campinas, Campinas, Brasil.

5 Population Council do Brasil, São Paulo, Brasil.

Correspondence F. J. M. Viana Maternidade Odete Valadares, Fundação Hospitalar de Minas Gerais. Rua Felipe dos Santos 63 apto. 201, Belo Horizonte, $M G$ 30180-160, Brasil. fviana_psc@bol.com.br fviana.prof@newtonpaiva.br
}

\begin{abstract}
A cross-sectional study was conducted to evaluate factors associated with safe sex among sexually active public school students in Minas Gerais State, Brazil. The study focused on correlations between the variables gender, age, schooling, current grade, ethnicity, religion, importance attributed to religion, mothers' education, prior exposure to any sex education, promotion of juvenile protagonism, and participation by health professionals in school activities and consistent condom use with casual or stable partners and with use of other modern contraceptive methods. Bivariate and multivariate logistic regression analyses were used. Male gender and participation by health professionals in school activities were positively associated with all indicators of safe sex, and maternal schooling of more than eight years was positively associated with consistent condom use with casual and stable partners. Secondary (versus elementary) schooling and age (older) were inversely associated with consistent condom use with casual and stable partners, respectively. Ascribing greater importance to religion and Evangelical religion were negatively associated with use of modern contraceptives in the last sexual intercourse.
\end{abstract}

Adolescent; Safe Sex; Students
Francisco José Machado Viana 1,2

Anibal Faúndes 3,4

Maeve Brito de Mello 5

Maria Helena de Sousa 3

\section{Introduction}

There is general agreement on the advantage of providing children and adolescents with some form of sex education by trained professionals. One aim of sex education is to encourage adolescents to adopt responsible sexual behavior in order to protect their physical and psychological health as well at that of their sexual partners.

The Brazilian Ministry of Education has issued guidelines to include sex education in all school activities. However, since budget funds for teacher training have been extremely scarce, such activities are frequently limited to reproducing existing prejudices in Brazilian society 1 . The specific situation is no different in Minas Gerais, one of Brazil's largest States, located in the Southeast region of the country. The State had a population of $17,492,296$ according to the 2000 Census, distributed in 853 municipalities. Although some sex education initiatives had been conducted previously, in 1999 a broader public program was launched in 170 schools located in 41 municipalities Statewide. The socalled Programa de Educação Afetivo-sexual: Um Novo Olhar (Program for Affective and Sexual Education, A New View - PEAS), was carried out in collaboration with the Odebrecht Foundation, motivated by the need to prevent the spread of HIV among adolescents 2 .

The baseline survey to evaluate the program provided data to study the association between 
key factors and the adoption of safe sex behavior by sexually active students before the program activities were launched. In addition to socio-demographic characteristics, the study focused on other variables related to prior exposure to any intervention or activities developed at school that could influence the adoption of safe sex behavior: participation by health professionals in the school setting, the promotion of youth empowerment 3 , and prior participation in any sex education activity in any school they had attended.

Understanding the relationship between these variables and the adoption of safer sex practices helps orient the organization and implementation of sex education programs aimed at reducing the risk of STD/HIV infection and unwanted pregnancy in adolescents.

\section{Subjects and methods}

This was a cross-sectional study based on the baseline data from an evaluation of a sex education program (PEAS). The evaluation used a quasi-experimental design with pre and posttests and a non-equivalent control group. Program evaluation was performed by an external research team (CEMICAMP - Centro de Pesquisas Materno-Infantis de Campinas), which did not participate in selection of the municipalities or schools included in the program. Program managers decided that the program would be implemented initially in all 41 cities where the State Department of Education had regional offices. The program was implemented first in 20 municipalities, followed by another 21 a year later, based on the criteria of high STD/AIDS and drug-use prevalence. Four schools in each municipality were randomly selected from a list of schools providing classes at least from the $5^{\text {th }}$ to $8^{\text {th }}$ grades and whose principals were interested in including the program in their curriculum 4 .

\section{Selection of municipalities}

Twelve of the 41 municipalities were selected to take part in the evaluation process (six of the initial 20 and six of the 21 included in the program a year later). Each group of six municipalities was divided into two groups of three each, according to the proportion of the rural population in each micro-region of Minas Gerais State to which they belonged, based on data from the 2000 National Census. Thus, four groups of municipalities were established. Within each of the four groups, the three with the most public schools were selected to take part in the evaluation process, including a baseline and follow-up survey.

\section{Selection of schools}

Among the 12 municipalities, all four schools scheduled to take part in the program were included in the baseline survey, along with four schools with a similar socioeconomic profile and selected for comparison purposes based on data from the State Department of Education 5 and geographic proximity to the program participant schools.

\section{Selection of classrooms and students}

The last three grades of elementary school (grades 6 to 8 under the Brazilian system) and grades 1 and 2 of high school were included in the baseline survey. From this total, 19 classrooms for program and comparison schools were chosen using a systematic random sampling method. All students from the selected classrooms were invited to take part in the survey. Only those with previous sexual experience were included in the analysis that is the focus of this paper.

\section{Data collection}

The data collection instrument was a pre-tested, self-administered, multiple-choice questionnaire with 43 questions based on the program's specific objectives. For the purposes of this study, only questions related to socio-demographic characteristics, prior exposure to any sex education activity, students' perception of promotion of youth empowerment by schools, participation by health professionals in school activities, and sexual practices were analyzed. For the purposes of this study, sexual practices were defined as including any of the following sexual acts: oral sex and penile-vaginal and/or penile-anal contact or penetration. Reliability of the score-type questions in the instrument was assessed by Cronbach's alpha 6 .

When students were requested to complete the questionnaire, only those who agreed to participate and had a free informed consent form signed by both themselves and their parents or legal guardians remained in the room. The Research Ethics Committee of the Faculdade de Ciências Médicas, Universidade Estadual de Campinas approved the study protocol. Data were collected from September 25 to December 1, 2000.

\section{Sample size}

The sample size was calculated for the study considering the estimated proportion of $51 \%$ of sexu- 
ally active adolescents ages 10 to 19 who reported consistent condom use with stable partners to protect against STD/HIV/AIDS (unpublished data). Type I error (alpha) was set at 0.05 and expected absolute difference between sample and population proportion was set at $4 \%$, resulting in a sample size of 600 sexually active adolescents. Since the proportion of adolescents engaged in sexual activities in the above-mentioned study was found to be $39 \%$, at total of 1,540 was necessary to reach 600 sexually active adolescents.

\section{Data processing and analysis}

Data from the completed questionnaires were entered by two independent assistants using the SPSS Data Entry program and checked for consistency.

Independent variables were: gender, age, school grade attended (grade 6 to 8 of elementary school versus grades 1 and 2 of secondary high school), day or evening classes attended, ethnicity (white versus other), religion, importance ascribed to religion (very important versus other), maternal schooling ( $\leq$ versus $>8$ years), as well as participation in any sex education activity at the current or previous schools, school teachers' activities to promote juvenile protagonism, and participation by health professionals in school activities. A list of possible activities that could encourage juvenile protagonism was provided, and a score was based on the level of participation reported by students in each of the activities. Students were classified in two groups, using the median as the cut-off: greater or lesser exposure to juvenile protagonism. Dummy variables representing participation by health professionals in school activities and any prior sex education were also dichotomized as yes/no responses.

Dependent variables were: history of consistent condom use with casual or stable partners and use of modern contraceptive methods, i.e., condoms, IUD, and any hormonal methods, during the last sexual intercourse.

Bivariate analyses were performed to study the associations between the various independent variables and the three dependent variables, using the chi-squared test 7 . Multivariate logistic regression ${ }^{8}$ was used to determine which of the independent variables were associated with the sex practice variables. SPSS for Windows v. 6.0 (SPSS Inc., Chicago, USA) was used for the data analysis.

\section{Results}

\section{Sample characteristics}

Sexual activity with or without penetration was reported by 1,223 of 2,110 boys (58\%) and by 712 of 3,336 girls (21.3\%). Considering both male and female students, 1,935 of 5,446 (35.5\%) reported some sexual experience.

Nearly two-thirds of the adolescents who reported any sexual experience were male, almost $70 \%$ were between 15 and 19 years of age, and almost $40 \%$ were in the first two grades of high school, while just over one-fourth of their mothers had more than eight years of schooling. More than $70 \%$ declared non-white skin color, and 30\% attended night school. Nearly $75 \%$ reported being Catholic, and a similar proportion considered religion a very important issue in their lives (data not shown in tables).

\section{Safe sex behavior according to socio-demographic characteristics}

The proportion of boys reporting condom use with casual or stable partners and contraceptive use in last intercourse was 11 to 18 percentage points higher than among girls, a highly significant difference $(p<0.001)$. As compared to older students, a significantly higher proportion of younger students (10 to 14 years) reported condom use with stable partners $(\mathrm{p}<0.05)$ (Table 1$)$.

No correlation was found between day versus night school or skin color and any of the safe sex indicators. More elementary students used condoms with stable partners than did secondary students. More students whose mothers had more than eight years of schooling reported safe sex than did those whose mothers had less schooling, but this only reached statistical significance for condom use with casual and stable partners $(\mathrm{p}<$ 0.001 and $\mathrm{p}<0.005$ respectively) (Table 1 ).

Modern contraceptive use in the last intercourse was more common among self-identified Catholics ( $<$ 0.005) and those ascribing little importance to religion $(\mathrm{p}<0.05)$.

\section{Safe sex behavior according to prior contact with sex education activities}

From 57 to $61 \%$ of students reported always using condoms with casual partners and 51 to $54 \%$ with stable partners. Consistent condom use with casual or stable partners was at least three percentage points higher among students who reported ever having participated in sex education activities in school, but these differences were not statistically significant (Table 2). 
Table 1

Condom use with casual and stable partners and contraceptive use during last intercourse according to socio-demographic variables.

\begin{tabular}{|c|c|c|c|c|c|c|}
\hline \multirow[t]{2}{*}{$\begin{array}{l}\text { Student } \\
\text { characteristics }\end{array}$} & \multicolumn{2}{|c|}{$\begin{array}{l}\text { Consistent condom } \\
\text { use with casual } \\
\text { partners }\end{array}$} & \multicolumn{2}{|c|}{$\begin{array}{l}\text { Consistent condom } \\
\text { use with stable } \\
\text { partners }\end{array}$} & \multicolumn{2}{|c|}{$\begin{array}{l}\text { Modern contraceptive } \\
\text { use in last sexual } \\
\text { intercourse }\end{array}$} \\
\hline & $\%$ & $\mathrm{n}$ & $\%$ & $\mathrm{n}$ & $\%$ & $n$ \\
\hline \multicolumn{7}{|l|}{ Gender } \\
\hline Male & $64.1^{\star \star \star}$ & 849 & $60.6^{\star \star \star}$ & 601 & $74.4^{\star \star \star}$ & 996 \\
\hline Female & 49.4 & 389 & 42.3 & 475 & 63.0 & 525 \\
\hline \multicolumn{7}{|l|}{ Age (years) } \\
\hline $10-14$ & 57.5 & 362 & $57.9^{*}$ & 280 & 67.7 & 421 \\
\hline $15-19$ & 60.2 & 877 & 50.7 & 797 & 71.5 & 1,101 \\
\hline \multicolumn{7}{|l|}{ School grade } \\
\hline Elementary, 6 th to 8 th & 60.9 & 752 & $57.4^{\star \star \star}$ & 625 & 70.3 & 920 \\
\hline Secondary, 1st-2nd & 57.1 & 487 & 45.8 & 452 & 70.6 & 602 \\
\hline \multicolumn{7}{|l|}{ Study period } \\
\hline Day & 60.1 & 835 & 53.1 & 719 & 69.0 & 1,031 \\
\hline Night & 57.9 & 404 & 51.4 & 358 & 73.5 & 491 \\
\hline \multicolumn{7}{|l|}{ Skin color } \\
\hline White & 61.6 & 346 & 52.8 & 303 & 71.5 & 428 \\
\hline Non-white & 58.5 & 889 & 52.3 & 771 & 70.0 & 1,090 \\
\hline \multicolumn{7}{|l|}{ Maternal schooling (years) } \\
\hline$\leq 8$ & 55.7 & 801 & 49.5 & 697 & 69.1 & 969 \\
\hline$>8$ & $69.5^{\star \star \star}$ & 302 & $60.6^{\star \star}$ & 259 & 74.6 & 370 \\
\hline \multicolumn{7}{|l|}{ Religion } \\
\hline Catholic & 60.4 & 914 & 53.0 & 811 & $72.8^{\star \star}$ & 1,131 \\
\hline Evangelical, other, none & 56.0 & 318 & 50.8 & 262 & 63.3 & 384 \\
\hline \multicolumn{7}{|l|}{ Importance of religion } \\
\hline Very important & 59.1 & 888 & 53.3 & 780 & 69.1 & 1,097 \\
\hline Other & 60.3 & 345 & 50.7 & 290 & $74.5^{\star}$ & 415 \\
\hline
\end{tabular}

* $<0.05$;

$\star *<0.005$;

$\star \star \star<0.001$ Chi-squared test with Yate's correction.

Table 2

Percentage of male and female students who reported safe sex practices according to prior exposure to sex education activities at school.

\begin{tabular}{|c|c|c|c|c|}
\hline \multirow{3}{*}{ Safe sex practices } & \multicolumn{4}{|c|}{ Sex education } \\
\hline & \multicolumn{2}{|c|}{ Yes } & \multicolumn{2}{|c|}{ No } \\
\hline & $\%$ & n & $\%$ & $\mathbf{n}$ \\
\hline \multicolumn{5}{|l|}{ Consistent condom use } \\
\hline with casual partners & 61.4 & 666 & 57.4 & 545 \\
\hline \multicolumn{5}{|l|}{ Consistent condom use } \\
\hline with stable partners & 54.1 & 560 & 51.0 & 492 \\
\hline \multicolumn{5}{|l|}{ Modern contraceptive use } \\
\hline during last sexual intercourse & 72.9 & 790 & 68.3 & 700 \\
\hline
\end{tabular}


Some $70 \%$ of students reported using modern contraceptive methods during their last intercourse. The percentage was higher among those who reported having participated in any sex education activities at school, but the difference was not statistically significant (Table 2).

There was practically no difference in condom use with casual or stable partners or modern contraceptive use during last sexual intercourse, based on studying in a school setting that encouraged juvenile protagonism (Table 3 ).

The percentage of students who reported safe sex practices was higher among those in schools with health professionals participating. The differences were statistically significant for consistent condom use with casual partners and modern contraceptives during the last sexual intercourse (Table 4).
Multivariate logistic regression analysis showed that male gender and attending schools with health professionals involved in school activities were positively associated with all indicators of safe sex, and maternal schooling of more than eight years was positively associated with consistent condom use with casual and stable partners.

High school students (as compared to elementary) and older students were inversely associated with consistent condom use with casual and stable partners, respectively. Ascribing greater importance to religion and Evangelical religion were inversely associated with use of modern contraceptives in last sexual intercourse (Table 5).

Table 3

Percentage of male and female students who reported safe sex practices according to promotion of youth empowerment by schools.

\begin{tabular}{|c|c|c|c|c|}
\hline \multirow{3}{*}{ Safe sex practices } & \multicolumn{4}{|c|}{ Promotion of juvenile protagonism } \\
\hline & \multicolumn{2}{|c|}{ Yes } & \multicolumn{2}{|c|}{ No } \\
\hline & $\%$ & $\mathbf{n}$ & $\%$ & $\mathbf{n}$ \\
\hline \multicolumn{5}{|l|}{ Consistent condom use } \\
\hline with casual partners & 60.0 & 470 & 59.3 & 585 \\
\hline \multicolumn{5}{|l|}{ Consistent condom use } \\
\hline with stable partners & 53.5 & 404 & 51.0 & 508 \\
\hline \multicolumn{5}{|l|}{ Modern contraceptive use } \\
\hline during last sexual intercourse & 71.5 & 572 & 70.1 & 723 \\
\hline
\end{tabular}

Table 4

Percentage of students who reported safe sex practices according to participation by health professionals in school activities.

\begin{tabular}{|c|c|c|c|c|}
\hline \multirow{3}{*}{ Safe sex practices } & \multicolumn{4}{|c|}{ Participation by health professionals in the school } \\
\hline & \multicolumn{2}{|c|}{ Yes } & \multicolumn{2}{|c|}{ No } \\
\hline & $\%$ & $\mathrm{n}$ & $\%$ & n \\
\hline \multicolumn{5}{|l|}{ Consistent condom use } \\
\hline with casual partners & 65.3 & 429 & $57.2^{\star}$ & 761 \\
\hline \multicolumn{5}{|l|}{ Consistent condom use } \\
\hline with stable partners & 56.3 & 375 & 50.7 & 667 \\
\hline \multicolumn{5}{|l|}{ Modern contraceptive use } \\
\hline during last sexual intercourse & 75.4 & 520 & $67.8^{\star \star}$ & 945 \\
\hline
\end{tabular}

* $\mathrm{p}=0.007$

$\star \star p=0.003$ 
Variables associated with safe sex practices in multivariate logistic regression analysis.

\begin{tabular}{|c|c|c|c|c|c|c|}
\hline & \multicolumn{4}{|c|}{ Consistent condom use with } & \multirow{2}{*}{\multicolumn{2}{|c|}{$\begin{array}{l}\text { Modern contraceptive } \\
\text { use during last sexual } \\
\text { practice } * *(n=1,098)\end{array}$}} \\
\hline & Cast & & $\begin{array}{r}\text { Stak } \\
*\end{array}$ & & & \\
\hline & $\begin{array}{c}\text { OR } \\
(95 \% \mathrm{Cl})\end{array}$ & $p$ & $\begin{array}{c}\text { OR } \\
(95 \% \mathrm{Cl})\end{array}$ & $p$ & $\begin{array}{c}\text { OR } \\
(95 \% \mathrm{Cl})\end{array}$ & $p$ \\
\hline $\begin{array}{l}\text { Participation by } \\
\text { health professionals }\end{array}$ & $\begin{array}{c}1.48 \\
(1.12-1.95)\end{array}$ & $<0.006$ & $\begin{array}{c}1.37 \\
(1.01-1.87)\end{array}$ & $<0.044$ & $\begin{array}{c}1.42 \\
(1.07-1.90)\end{array}$ & $<0.016$ \\
\hline Gender (male) & $\begin{array}{c}1.54 \\
(1.24-1.92)\end{array}$ & $<0.001$ & $\begin{array}{c}2.03 \\
(1.51-2.73)\end{array}$ & $<0.001$ & $\begin{array}{c}1.50 \\
(1.14-1.97)\end{array}$ & $<0.003$ \\
\hline Age (years) & - & - & $\begin{array}{c}0.87 \\
(0.79-0.95)\end{array}$ & $<0.002$ & - & - \\
\hline $\begin{array}{l}\text { Maternal schooling } \\
\text { (> } 8 \text { years) }\end{array}$ & $\begin{array}{c}1.80 \\
(1.31-2.47)\end{array}$ & $<0.001$ & $\begin{array}{c}1.47 \\
(1.06-2.04)\end{array}$ & $<0.022$ & - & - \\
\hline $\begin{array}{l}\text { Importance of religion } \\
\text { (very important) }\end{array}$ & & & & & $\begin{array}{c}0.71 \\
(0.52-0.96)\end{array}$ & $<0.027$ \\
\hline $\begin{array}{l}\text { Grade (1st and 2nd, } \\
\text { secondary school) }\end{array}$ & $\begin{array}{c}0.77 \\
(0.60-0.98)\end{array}$ & $<0.031$ & - & - & - & - \\
\hline $\begin{array}{l}\text { Religion } \\
\text { (Evangelical) }\end{array}$ & - & - & - & - & $\begin{array}{c}0.61 \\
(0.43-0.88)\end{array}$ & $<0.008$ \\
\hline
\end{tabular}

* Constant: $p=0.017$

** Constant: $p<0.001$

\section{Discussion}

Based on the results, male adolescents were more apt to practice safe sex than girls, which agrees with the known greater power of males than females to determine the conditions of their sexual practices 9 . These results also agree with those of various other authors who also found that safe sex is more common in male as compared to female adolescents 10,11,12,13.

Increased condom use with stable partners as reported by younger students is consistent with studies in other countries 14 and with the prevalence of condom use by age shown by the 1996 Demographic and Health Survey 15.

Another observation in the same direction is the inverse association between condom use with casual partners and the grade in school. A study of students in Africa found the opposite, whereby those with more schooling used condoms more frequently, but the study included elementary, secondary, and university students 16 .

In the bivariate analysis, the higher proportion of Catholic students who used contraceptives in their last intercourse as compared to those with other religions came as a surprise. However, the multivariate regression showed that the difference was probably due to less frequent contraceptive use by Evangelical students rather than a higher proportion among Catholic students as compared to those with no religion.

On the other hand, the lower percentage of students using contraceptives among those ascribing great importance to religion is not surprising, since the religions with the most followers in Brazil tend to prohibit contraceptive use (except for abstinence) 13,17. Given the importance of safe sex practices to reduce the spread of STDs and HIV, our results should serve as a further call to local religious leaders who still attempt to block the use of condoms and other modern contraceptive methods. Even more untenable are their false arguments, like claiming that condoms fail to protect against HIV or that the emergency contraceptive pill induces abortion 18 , ignoring current scientific evidence to the contrary 19,20,21,22. The impact of their erroneous claims in condoning unsafe sexual behavior by 
their more devote followers, as observed in this study, can have tragic consequences that are totally unacceptable in a country like Brazil with a secular political system.

The higher proportion of students who practiced safe sex among those whose mothers had more schooling supports the concept of the home environment as a determinant factor for the sexual behavior of adolescents. It also appears to indicate that more parental schooling increases the chances for communication with children on matters as delicate and important as sexual behavior. Various other authors have shown that parents with more schooling tend to establish better communications about sex with their children 23.

The absence of correlation between prior exposure to sex education and safe sex practices was not a great surprise. In fact, the finding is consistent with the international experience with sex education programs that have evaluated their impact on sexual behavior. They have shown that sex education programs only have a positive effect on sexual behavior of adolescents if they meet certain conditions, like respect for the students' knowledge, a critical reflection on their educational practices, and ethics 24,25,26,27. Our results suggest that these conditions were probably not met by the variable "any prior exposure to sex education" evaluated in this study.

Likewise, student participation in extracurricular activities conducted by teachers may not be a good indicator of promoting "juvenile protagonism". Thus, while our results do not support a correlation between "empowerment" and safe sex practices, they do not rule out such a correlation. A more in-depth analysis of this issue would be useful in future studies.

Finally, the higher proportion of safe-sex adherents among adolescents enrolled in schools where health professionals participate in teaching activities was expected. Information on safe sex alone is not sufficient, if not accompanied by easy access to condoms and other contraceptive methods 28 . Ideally, condoms and other methods should be available in the schools, since adolescents feel inhibited from attending health care facilities, which are not "user-friendly" to them 29 . They often lack the money to purchase condoms and other methods in drugstores and are frequently reticent and fearful of being recognized by other customers 30 . Our results are thus consistent with current knowledge and help confirm the relevance of good coordination between the school system and health sector for the success of efforts to promote safe sex among adolescents.
We should recall that these results are part of a larger study designed not to determine population estimates, but to evaluate a sex education program, based on a quasi-experimental design. Therefore, the proportions of sexually active students and those practicing safe sex cannot be generalized to other groups of adolescents. Moreover, the associations found in this sample would not necessarily be repeated in the universe of public students in the cities where the study was conducted, much less for all the students in Minas Gerais State. On the other hand, there is no good reason to believe that these associations would be very different in other samples of male versus female adolescents or between more religious versus less religious students.

Few studies in Brazil have evaluated factors associated with the adoption of safe sex practices by adolescents. The main relevance of these results is that they suggest that gender differences persist among public school students, that merely any form of sex education may not be effective in changing behavior, that the health and educational sectors should join efforts to achieve their aims, that the home environment has a strong influence on sexual behavior, and that religion may have a negative effect on safe sex practices. All these findings may be useful to guide future interventions intended to promote safe sex practices among adolescents.

Given that our sample is not representative of Brazilian adolescents, it would be advisable to develop and implement a larger study with a representative sample of adolescents that would allow confirming or correcting some of these findings. 


\section{Resumo}

Foi realizado um estudo de corte transversal para avaliar fatores associados à prática de sexo seguro entre estudantes sexualmente ativos de escolas públicas de Minas Gerais, Brasil. Estudou-se a associação de sexo, idade, escolaridade, turno, cor da pele, religião e importância dada à religião, educação da mãe, exposição à educação sexual, promoção do protagonismo juvenil pela escola e participação de profissionais de saúde no ensino, com uso consistente de condom com parceiro casual ou fixo, e uso de anticoncepcionais modernos. Utilizou-se análise bivariada e regressão logística multivariada. Ser do sexo masculino e ter envolvimento de profissionais de saúde no ensino estiveram positivamente associados com todos os indicadores de sexo seguro, e uma mãe com mais de oito anos de escolaridade esteve positivamente associado com uso de condom com parceiro fixo ou casual. Ser aluno do Ensino Médio (versus Fundamental) e ser mais velho associaram-se negativamente com uso consistente de condom com parceiro casual e fixo, respectivamente. Dar grande importância à religião e ser evangélico estiveram negativamente associados ao uso de anticoncepcionais modernos na última relação sexual.

Adolescente; Sexo Seguro; Estudantes

\section{References}

1. Santos C, Bruns MAT. A educação sexual pede espaço: novos horizontes para a práxis pedagógica. São Paulo: Editora Omega; 2000.

2. Secretaria de Estado da Educação de Minas Gerais/Fundação Odebrecht. Afetividade e sexualidade na educação: um novo olhar. Belo Horizonte: Secretaria de Estado da Educação de Minas Gerais/Fundação Odebrecht; 1998.

3. Costa ACG. O adolescente como protagonista. In Schor N, Mota MSFT, Branco VC, organizadores. Cadernos: juventude saúde e desenvolvimento. Brasília: Ministério da Saúde, Secretaria de políticas de Saúde; 1999. p. 75-9.

4. Faúndes A, Mello MB. Pesquisadores responsáveis. Relatório da linha de base do "Programa de Educação Afetivo-Sexual: Um Novo Olhar”. Belo Horizonte: Secretaria de Estado da Educação e de Saúde de Minas Gerais/Fundação Odebretht/Centro de Pesquisas Materno-Infantis de Campinas; 2001.

5. Sistema Mineiro de Avaliação da Educação Pública. Proeb2000. Programa de avaliação da rede pública de educação básica. http://www.simave.ufjf.br/ proeb2003/resultados/ (accessed on 22/Nov/2002).

\section{Contributors}

All the authors participated in preparing the research protocol. M. B. Mello and M. H. Sousa participated in the data collection, and the four authors participated in the data analysis and wrote the article.
6. Cronbach LJ. Coefficient alpha and the internal structure of tests. Psychometrika 1951; 16:297-334.

7. Berquó ES, Souza JMP, Gotlieb SLD. Bioestatística. 2ạ Ed. São Paulo: EPU; 1981.

8. Hosmer DW, Lemeshow S. Applied logistic regression. New York: John Wiley \& Sons; 1989.

9. Paiva V. Fazendo arte com camisinha - sexualidades jovens em tempos de AIDS. São Paulo: Summus Editorial; 2000.

10. Paiva V. Em tempos de Aids: sexo seguro, prevenção, drogas, adolescentes, mulheres, apoio psicológico aos portadores. São Paulo: Summus Editorial; 1992.

11. Ferreira SMB, Pinheiro VNS, Sá EVM, Alvarenga GC. Uso de preservativo por adolescente de um colégio estadual em Niterói - RJ. DST J Bras Doenças Sex Transm 1998; 10:13-9.

12. Vieira NFC. Sexualidade, DST/Aids e adolescência: não quero falar, tenho vergonha. DST J Bras Doenças Sex Transm 2001; 13:46-51.

13. Rede Feminista de Saúde. Adolescentes, saúde sexual e saúde reprodutiva: dossiê. Belo Horizonte: Rede Feminista de Saúde; 2004. 
14. Shrier LA, Goodman E, Emans J. Partner condom use among adolescent girls with sexually transmitted diseases. J Adolesc Health 1999; 24:357-61.

15. Sociedade Civil Bem-Estar Familiar no Brasil/ Macro International Inc. Pesquisa Nacional sobre Demografia e Saúde, 1996. Rio de Janeiro: Sociedade Civil Bem-Estar Familiar no Brasil/Macro International Inc.; 1997.

16. Moreau JC, Fave O, Havatou D, Fave EO, Badiane $\mathrm{M}$, Diadhiou F. Use of the male condom at schools and universities: survey with 1065 young people. Dakar Med 2002; 47:229-33.

17. Moser A. Planejamento familiar: uma visão religiosa. In: Ribeiro M, organizador. O prazer e pensar: orientação sexual para educadores e profissionais de saúde. v. 2. São Paulo: Editora Gente; 1999. p. 253-60.

18. Hardy E, Duarte GA, Osis MJ, Arce XE, Possan M. Anticoncepção de emergência no Brasil: facilitadores e barreiras. Cad Saúde Pública 2001; 17:1031-5.

19. Durand M, Cravioto MC, Raymond EG, DuránSánchez O, Cruz-Hinojosa ML, Castell-Rodríguez A. On the mechanisms of action of short-term levonorgestrel administration in emergency contraception. Contraception 2001; 64:227-34.

20. Marions L, Hultenby K, Lindell I, Sun X, Stabi B, Danielsson KG. Emergency contraception with mifepristone and levonorgestrel: mechanism of action. Obstet Gynecol 2002; 100:65-71.

21. Croxatto HB, Devoto L, Durand M, Ezcurra E, Larrea F, Nagle C. Mechanism of action of hormonal preparations used for emergency contraception: a review of the literature. Contraception 2001; 63:111-21.

22. Ortiz ME, Ortiz RE, Fuentes MA, Parraguez VH, Croxatto HB. Post-coital administration of levonorgestrel does not interfere with post-fertilization events in the new-world monkey Cebus apella. Hum Reprod 2004; 19:1352-6.
23. Lefkowitz ES, Boone TL, Kit-fong Au T, Sigman M. No sex or safe sex? Mother's and adolescents' discussions about sexuality and AIDS/HIV. Health Educ Res 2003; 18:341-51.

24. Kirby D. The impact of schools and schools programs. Upon adolescent sexual behavior. J Sex Res 2002; 39:27-33.

25. Robin L, Dittus P, Whitaker D, Crosby R, Ethier K, Ches JM. Behavioral interventions to reduce incidence of HIV, STD, and pregnancy among adolescents: a decade in review. J Adolesc Health 2004; 34:3-26.

26. Freire P. Pedagogia da autonomia: saberes necessários à pratica educativa. 14a $\mathrm{Ed}$. Rio de Janeiro: Paz e Terra; 1996.

27. Speizer IS, Magnani RJ, Colvin CE. The effectiveness of adolescent reproductive health interventions in developing countries: a review of the evidence. J Adolesc Heath 2003; 33:234-48.

28. Berquó E, coordenadora. Comportamento sexual da população brasileira e percepções do HIV/ AIDS. Brasília: Secretaria de Políticas de Saúde, Ministério da Saúde; 2000. (Série Avaliação, 4).

29. Ministério da Saúde. Sexualidade, prevenção das DST/AIDS e uso indevido de drogas - diretrizes para o trabalho com crianças e adolescentes. Brasília: Secretaria de Políticas de Saúde, Ministério da Saúde; 1998.

30. Ayres J, Calazans G, França Jr. I. Vulnerabilidade do adolescente ao HIV/AIDS. In: Vieira E, Fernandes M, Bailey P, McKay A, organizadores. Seminário gravidez na adolescência. Rio de Janeiro: Associação Saúde da Família/Women's Studies Project/ Family Health International/US Agency for International Development; 1998. p. 97-109.

Submitted on $10 /$ Nov/2004

Final version resubmitted on 18/Oct/2005

Approved on 14/Nov/2005 